\title{
Globo H Antibody
}

National Cancer Institute

\section{Source}

National Cancer Institute. Globo H Antibody. NCI Thesaurus. Code C118194.

Any immunog lobulin that recognizes the hexasaccharide antigen Globo $\mathrm{H}$. 